\title{
Towards a unified framework for anti-bribery in sport governance
}

\author{
Christina Philippou \\ University of Portsmouth
}

\section{Abstract}

There is limited literature focusing on bribery and corruption in private or quasi private sector companies and associations in general, and on sport governing bodies in particular. This paucity of knowledge in the theoretical sphere impedes critical analysis on bribery in practice, and does not allow for application of anti-bribery and corruption ("ABC") measures grounded in research. The purpose of this paper is to inform anti-bribery and corruption research and practice by producing an original framework to facilitate critical analysis of bribery and development of $A B C$ policies. This paper analyses and amalgamates relevant interdisciplinary literature, from areas of corporate governance, economics, politics, sociology, sports science, law, and criminology, to produce a unified theoretical anti-bribery framework made up of three elements: clarifying concepts, assessing risk factors, and assessing governance. The framework can be applied to critical assessment of bribery and/or sport governance $A B C$ initiatives by researchers, forensic accountants, internal auditors, and compliance and governance officials both within and outside the sport sector.

Keywords: Corruption, bribery, corporate governance, sport governance

\section{Introduction}

Bribery and corruption in sport is arguably as old as organised sport competition itself: there are sixteen statue bases surviving in ancient Olympia today built as penance by those caught engaging in 
corruption at the Olympic Games (Spivey, 2012). The first modern sports to involve corruption were boxing and baseball (Cashmore and Dixon, 2016), with match-fixing in the 1919 World Series bringing the latter into disrepute (Fountain, 2016, Ferguson, 2016, Nuwer, 1994). Bribery continues today, and is intrinsically linked with other forms of corruption, including vote-rigging, cronyism, and fund misappropriation in, amongst others, football (Blake and Calvert, 2015, Youd, 2014, Menary, 2016, Garcia and Norbely, 2014, De Sanctis, 2014), cycling (Albergotti, 2014, Marty et al., 2015), cricket (De Speville, 2012, Lord Woolf and PricewaterhouseCoopers, 2012, Kimber et al., 2015, Ray, 2016), athletics (Sadoff, 2016, Roan, 2016, Daly and Oliver, 2016, Mason et al., 2006), and volleyball (Pielke, 2016).

This paper's contribution to knowledge is twofold: a review of interdisciplinary corruption literature relevant to sport governance and the production of a framework for critically analysing bribery or adopting anti-bribery and corruption ("ABC") initiatives grounded in academic theory. It is aimed at application in sport governance $A B C$ initiatives by compliance and governance officials in sport governing bodies ("SGBs") and international sport governing bodies ("ISGBs"), although can be adapted for analysis in other industries or for other forms of financial corruption.

The paper is structured as follows: corruption and bribery are defined, and the reasons why sport is considered an industry analysed. A literature review is undertaken of the main disciplines contributing to theories of bribery and $\mathrm{ABC}$ in sport governance to produce an anti-bribery framework, providing suggestions for further research before concluding.

\section{Corruption}

There are multiple definitions of corruption in use, including "the abuse of public office for private gain" (Quiñones, 2000) and "the abuse of entrusted power for private gain" (Transparency International, 2017a). These definitions emphasise individual gain, so do not capture bribes taken or 
given for the benefit of an employer or voluntary organisation (Ashforth and Anand, 2003), although this can indirectly be for private gain (by aiding the organisation that funds or enhances the reputation of the bribe-payer/ bribe-taker). Den Nieuwenboer and Kaptein (2008) attempt to rectify this by including "subunit and/or organisational" beneficiaries of bribe in their definition. However, this does not include "noble cause" corruption (Caiden, 2001, cited in Masters, 2016), where the gain in question is public rather than private and/or organisational.

Other limitations include irrelevance to athletes (Gorse and Chadwick, 2010) because corruption involving underperformance is not covered (for examples of these, see The Telegraph, 2010, Weaver, 2010, Reid, 2014, Albergotti, 2014).

Definitions of corruption have diverse foci, making measurement and enforcement difficult. For example, Rose (2017) tests seven scenarios against eight definitions of corruption from the historical to the Transparency International (2017a) one noted above. There is inconsistency in classifying scenarios as corrupt (or not) across these, even with non-moralistic definitions where personal or cultural ethical bias is not involved. This has broader implications for any corruption theory or framework, as the definition used affects the outcome.

Corruption literature appears in varied academic fields. No matter the approach, corruption is deemed, with few exceptions, to have negative effects on a country or industry (Paolo Mauro, 1995, Omar Azfar et al., 2001, Rose-Ackerman, 1978, Fisman and Golden, 2017). In sport, corruption can present itself in the (non-exhaustive) forms set out in Table 1 (Brooks et al., 2013, Maennig, 2005, Ionescu, 2015, Schenk, 2016, Pielke, 2016, Carpenter, 2016, Masters, 2015). 


\section{Governance}

- Cronyism

- Vote-rigging

- Illegal disclosure of inside information

- Conflict of interest

- Bribery (event allocation; posts of authority)

- Abuse of authority and trading in influence

- Money laundering

- Fund misappropriation, fraud, and embezzlement

\section{Athletes and other stakeholders}

- Doping

- Cheating

- Collusion

- Match-fixing

- Bribery (player transfers; match-fixing)

There is often an interaction between bribery and other forms of corruption. For example, when cyclist Lance Armstrong (winner of seven Tour de France titles prior to being stripped of them in October 2012) admitted to consistent drug use (Marty et al., 2015, Walsh, 2013, Hamilton and Coyle, 2013), allegations arose at subsequent lawsuits of bribing an opposing team to not challenge Armstrong in a race (Albergotti, 2014).

Match-fixing, the manipulation of sporting contests to yield pre-determined results (Plachta, 2014, Manoli and Antonopoulos, 2015, Hill, 2010, Rodenberg and Kaburakis, 2013, Kyprianou, 2015), often involves bribery of referees, players, managers, or agents (Agius, 2018, Al Jazeera Investigations, 2018, BBC, 2018, Blake, 2016, Mitchell, 2018, UEFA, 2018, Wu, 2018). European policymakers have 
concentrated on this form of corruption (European Commission, 2007, Council of Europe, 2014, European Parliament, 2011, European Parliament, 2012). Like doping, match-fixing is rarely undertaken by governance officials, as they can rarely influence the competition/game/match result (although exceptions exist where they influence or cover up athletes' corrupt behaviour).

Corruption in sport can also be classified according to organisational role, rather than type. Maennig (2005) classifies corruption into competition corruption (affecting results) and management corruption ("non-competition-focused decisions" like host venue allocation). Table 1 distinguishes between forms of corruption typically undertaken by governance officials and those by athletes, referees, or other stakeholders. Maennig's (2005) typology offers a useful distinction, but acts of bribery can occur in both classes.

Graycar (2015) developed the TASP (Type, Activity, Sector, Place) approach to analysing corruption (Adam and Aiden, 2012). This reflects on those four aspects of corrupt behaviours in their event typology. Masters (2015) applied this method to sport, including match-fixing and insider information. This classification system is useful at the individual level, and should be considered in case study analysis in conjunction with the framework developed in this paper.

\section{Bribery}

Business corruption often focuses on bribery (Transparency International, 2017b, ICAEW, 2017). Most empirical and experimental studies of bribery are concerned with public sector corruption, limiting coverage to monopolistic or oligopolistic and/or public good industries. It is therefore very country-specific, and less affected by the globalised nature of most private sector goods and services trade. 
Like corruption, bribery encompasses an array of definitional issues. The US Foreign Corrupt Practices Act (FCPA) of 1977 defines bribery as the act of "offering to pay, paying, promising to pay, or authorizing the payment of money or anything of value to $a[n]$... official in order to influence any [official] act or decision ... or to secure any other improper advantage in order to obtain or retain business" (US DOJ and SEC, 2012). This excludes elements of bribery defined by other legislation with global reach, discussed in more detail in the enforcement section.

Transparency International's (2017a) definition of bribery is broader: it includes "offering, promising, giving, accepting or soliciting of an advantage as an inducement for an action which is illegal, unethical or a breach of trust". However, further clarification on the terms "ethics" and "breach of trust", as well as jurisdiction for "legality", would enhance the robustness of this definition.

Further elements for a broader definition of bribery include unactioned bribery, where the offer/ receipt is agreed in theory but not acted on or paid in practice. There are some examples of this during allegations of match-fixing in tennis (see Mitchell, 2016, Blake, 2016) and baseball (Rader, 2008).

The typology of bribery is complex, as is the inter-relation between bribery and sport. Bribery has been linked to varied stakeholders. Athletes have come under scrutiny for accepting bribes, including NBA star LeBron James in 2003 for accepting vintage tops from a fan in breach of NCAA rules (Batchelor, 2005b). They have also been known to offer bribes, such as in the case of F1 driver Jack Brabham in 1956, who bribed the ship's captain to go faster so as to make it to his race (Collings, 2001). Coaches and club owners have been embroiled in bribery scandals, such as early 1900s Michigan Wolverines' American football coach Fielding H. Yost bribing players with explicitly prohibited cash incentives for points scored (Nuwer, 1994). Agents, too, have offered bribes to get players or owners to sign or deal with them (Nuwer, 1994, Smith, 2016, The Secret Footballer, 2013). 
Sponsor (Bruno, 2017, Smit, 2006, Yost, 2010) and league owner (Cashmore and Dixon, 2016) implication in match-fixing and other forms of bribery has also occurred, such as Bernie Ecclestone's alleged bribing of a bank's risk officer to facilitate a company stake sale in 2006 (Le Blond, 2014). Governing officers employed by, or acting on behalf of, SGBs are often found at the top of the hierarchical pyramid, yet have still been implicated in bribery. It is on these latter actors that the remainder of the paper will concentrate.

\section{The sport industry}

The market for global sport and sport-related goods and services flourished with the emergence of lucrative broadcast rights and sponsorship agreements in the 1990s (Beech and Chadwick, 2013, Gorse and Chadwick, 2010, Barker, 2013) continues to grow (Pielke, 2016, Gardiner et al., 2017). The sport industry is diverse, encompassing a broad range of individuals, practices, and organisations, with a large and varied list of stakeholders.

The sports industry is unique (Stewart and Smith, 1999), with its inelastic consumer base of fans (Kunkel et al., 2016), deep-rooted links with government spending (Groeneveld, 2009, Masters, 2015), the perception of sport as a public good (Geeraert et al., 2013, Groothuis et al., 2004), and its special treatment under international and EU law allowing self-governance (Chappelet, 2016a). The industry's status of autonomy is evident in the European Sports Charter, which recognises sports organisations' "autonomous decision-making processes within the law." (Council of Europe, 2001, Article 3.3).

The corporate governance of SGBs and ISGBs is important to stakeholders, which include governments funding stadia and other sport-related infrastructure (Groeneveld, 2009, Schwarz et al., 2017, Masters, 2015), and fans and sponsors affected by the lack of ethical integrity displayed by some organisations (Carpenter, 2016, Gorse and Chadwick, 2010, Hughes, 2018). 
While the industry is made up of voluntary sports organisations and affiliated sporting goods and services providers, the former benefit from autonomy. These tend to be hierarchically structured non-profit organisations (Garcia, 2017), usually governed by rules and regulations of their global governing body. In this paper, an ISGB is defined as an organisation at the top of the global governance hierarchy of a single sport (or group of sports, as in the case of the International Ski Federation, whose governance extends over snowboarding (FIS, 2018)), in line with typologies in Forster and Pope (2004) and Geeraert et al. (2014). It may have multiple regional and national associations reporting to it, feeding into it, or forming part of its membership. An SGB is defined as a local (often country association, such as the English Football Association) or regional (such as UEFA, which reports to FIFA) sport governing association.

Some researchers argue that SGBs and ISGBs should be treated as corporations (Barker, 2013, Szymanski and Kuypers, 2000). Smith and Stewart (2010) find four unique features of the sport industry (down from ten in the 1990s). Autonomy in sport is characterised by physical skill or gamesmanship (Steenbergen and Tamboer, 1998, Breivik, 2000), both subject to intense professionalisation (see Batchelor, 2005a, Rayner, 2018). This affects sport's standing as a noncorporatised industry. Furthermore, the autonomy carve-out affects competition legislation in the US and Europe, allowing oligopolistic league systems that restrain trade (Walsh and Giulianotti, 2007), further increasing profits of these organisations.

SGBs' and ISGBs' development into major revenue-generating organisations has increased their media profile, further enhancing the need for ethical conduct (and accountability thereon). Professionalisation of athletes, documented in Ancient Rome (Spivey, 2012), eventually led to mass commercialisation of sport (Collins, 2017, Kohe, 2017, Rayner, 2018). Globalisation has increased the reach of sports beyond their original borders (see Ziewacz, 2005, Hughson, 2017), increasing 
revenue and, through that, economic rents (covered in greater detail in subsequent sections). The effect of sponsorship on levels from professional through to grassroots has been well-documented (see Beech and Chadwick, 2013, Beech, 2013, Barker, 2013, Batchelor, 2005a, Smit, 2006), affecting athletes' kits (McMasters, 2005) to venue names (Walsh and Giulianotti, 2007).

Revenue incentives extend to sporting rules. For example, broadcast needs led to the 3-point line adoption in basketball (Ziewacz, 2005), ball colour changes in football and tennis, and reflective pucks introduced in ice hockey (Blödorn, 1988, cited in Steenbergen \& Tamboer, 1998, p. 45).

PWC (2011) calculated 2010 global sport revenues at $\$ 121$ billion, with the European football market revenue alone worth $€ 25.5$ billion in 2016/17 (Deloitte, 2018). US revenues in 2015 from gate receipts, media rights, sponsorship, and merchandising were $\$ 64$ billion (PWC, 2016). TV licensing revenue in the NBA alone a decade earlier accounted for $\$ 2$ billion (Fisher, 2005). This is in line with published financial statements of larger ISGBs, which report revenues of USD millions (see ICC, 2017, UCI, 2017, FIFA, 2017).

It is not only stakeholders within the industry that profit(ed) from the rapid growth and large revenues exhibited by sport leagues and organisations. For example, football pools across European countries use funds derived from their gambling customer base to re-invest in the sport (Huggins, 2017, Kohe, 2017) or other charities (Smith, 2016). There have also been stakeholder losses, including those from tax avoidance and/or evasion (Buschmann and Wulzinger, 2018). All these elements combine to highlight sport as an industry continuing to grow geographically and financially. It therefore follows that any anti-bribery framework for SGBs and ISGBs should treat them in similar ways to large private or publically-listed companies. This idea forms the basis of the framework derived from an amalgamation of financial corruption literature, as shown in Figure 1. 
Figure 1: Inputs and applications of interdisciplinary theoretical corruption perspectives

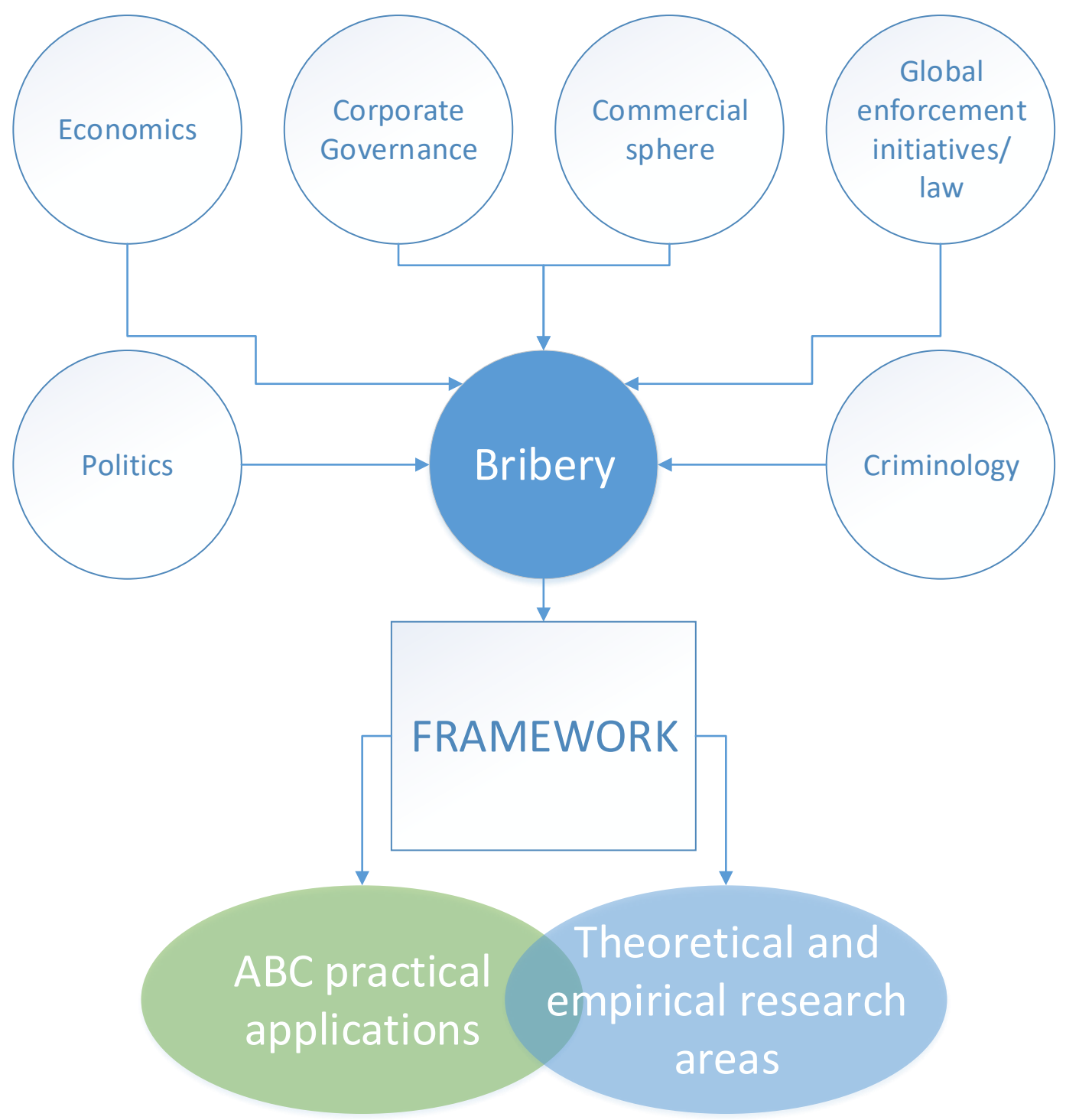

This process is what the remainder of the paper focuses on.

Politics

Traditionally, literature on corruption concentrated on either abuse of public office or bribery involving at least one public sector worker (Klitgaard, 1988, Klitgaard, 1998, Azfar et al., 2001, Goudie and Stasavage, 1998). This public sector bias in definitions appears to have diminished in more recent literature (see Miari et al., 2015), but continues due to corruption literature's politics base. 
Attempts to empirically model corruption include Klitgaard's (1988) corruption formula:

Corruption $=$ Economic Rent + Discretionary powers - Accountability

Elements that enhance country corruption levels are the presence of economic rent, levels of discretionary powers held by administrators, and a lack of accountability of those in office (Klitgaard, 1988). Accountability's importance is supported by findings that improved accounting and audit quality have negative effects on perceived corruption (Malagueño et al., 2010). However, care must be taken with the notion of accountability, especially in the absence of a strong definition and power for those holding potentially corrupt agents to account (Cooper and Johnston, 2012).

Rose-Ackerman (1999) concentrates on similar elements in her three dimensions of political corruption:

- "narrowly focused favours available for distribution", or discretionary powers;

- economic rent available (legally); and

- "the temporal stability of political alliances".

The latter has implications for, and links with, accountability, and is supported by LambertMogiliansky's (2002) findings of increased corruption in areas with unstable legislative and administrative functions.

Jain (2001) further adapts this to a framework of corruption with discretionary powers, economic rents, and punishments (both available and used) for breach. Similarly, Nichols (2012) adapts rational choice theories to include secrecy surrounding proceeds of bribery, perception of detection, and emotional and psychological costs of corrupt actions. 
Clarke and Xu (2004) analyse bribery in transition economy utility sectors, and findings support the idea that corruption is more likely where economic rents are high, competition low, and profits high (Ades and Di Tella, 1999). Global enforcement (discussed later in this paper) is based on this understanding of corruption.

In summary, economic rent, discretionary powers, accountability, and enforcement are all elements of various frameworks of political corruption.

\section{Economics}

Economic literature on the causes and effects of corruption focuses on agency theory, where principals (usually government) allocate resources to agents (usually government officers) with different aims to their allocators (see Mason et al., 2006), or rational choice theory (Becker, 1968, Rose-Ackerman, 1978). For SGBs and ISGBs, agency theory would see sponsors as principals (or fans under stakeholder theory) and governing officials as agents (and also those determining their preferences under rational choice theory). Recent experimental studies attempt to explain corruption in the economic literature.

Lambsdorff and Frank (2011) look at reciprocity of bribe-giving, concluding that one-shot games encourage distrust and therefore decrease bribery. This has implications for encouraging staff rotation in SGBs, something supported by Abbink's (2004) findings, where diminishing corruption exists in areas of increased staff rotation. However, this solution to governance corruption is complicated by the idea of network governance. This is where constant interplay between agents exchanging resources and achieving shared goals through teamworking is embedded within the structure of the organisation (Garcia, 2017), such as the interplay between national SGBs, regional SGBs, and ISGBs. Although this concept involves a public agent, it can be adapted to private sector agents because the public-sector nature is not fundamental to the framework's representation of 
the phenomenon. Network governance is inevitable in global organisations with relatively small boards, as SGB and ISGB officials are not independent agents and have to work together in multi-set game interactions. This is not to say that large boards would provide a solution, as too large boards create inefficiency and lack of cohesion between executives, amongst other issues (Lipton and Lorsch, 1992, Xie and Yukio, 2013, Yermack, 1996).

Ryvkin et al. (2017) find harassment bribes in public sector offices can be reduced through online reporting with specific locations divulged. This has implications for whistleblowing policies for SGBs, especially given inadequacies found in the context of doping (Cottrell and Erickson, 2018, Erickson et al., 2017). Furthermore, Lambsdorff and Frank (2010) find incentives for whistleblowers decrease reciprocity between potential bribe-takers and bribe-givers, and increase reporting of corrupt behaviour.

\section{Ethics}

"Integrity of sport" is a phrase commonly touted by SGBs and ISGBs (see IGF, 2016, Article 1, FIH, 2016, Article 1.4, IAAF, 2015, Article 27, Council of Europe and UEFA, 2018, Article 2). It is also used by stakeholding organisations, such as SIGA (2017) and WADA (Howman, 2013), and enforcement bodies such as Interpol (2018) and UNDOC (2018).

Corporate ethics often focus on whether social actions affect financial performance. Increasingly, integrity is becoming important for consumers (Rodgers et al., 2015) through the idea of public concern (Carroll, 1979). Integrity thus becomes important for sponsors, potentially leading to a double reduction in engaged stakeholders if the organisation's integrity is undermined. This was the case in the 2018 FIFA World Cup, with some sponsors distancing themselves (Hughes, 2018), although not all interpret integrity similarly because of differing aims (Chadwick, 2018). 
Sport is often contextualised within values and norms in society (Breivik, 2000). However, universalising these creates friction between them and the autonomy of sport (Steenbergen and Tamboer, 1998). Applied to SGBs and ISGBs, this autonomy/norms divide inevitably affects corruption, which, as previously noted, suffers from definitional issues (Rose, 2017) and a need for societal knowledge (Steidlmeier, 1999) to clarify ethically sound positions. What was defined as corruption when these governing bodies were set up, what the individuals acting as autonomous governing bodies define as corruption, and what the norms of the national and/or international community perceive as corruption do not necessarily align.

Sporting values and their competitive nature are not mutually exclusive under an ethics microscope, as the benefits from how sport "ritualizes, institutionalizes, redirects, disarms and detoxifies aggressive, destructive and dominating urges" (Skillen, 1998) can be positive to society in, for example, a utilitarian ethical view. The Michigan Wolverines, an American football college team, were told to "Solve your problems with aggression" (Furman et al., 2018, episode 3, 40:30-40:38) in the sporting arena. While such an attitude may spill over into societal conduct, such as in the cases of domestic violence allegations made against American footballers Ezekiel Elliot (Furman et al., 2018) or Greg Hardy (Gross, 2018), sporting values lie at the heart of both athlete and governing officer conduct, and exclude corruption.

Human action within sport affects ethical considerations attached to it. For example, Breivik (2000) distinguishes between "ontological chance" (including environmental and genetic factors) and "epistemological uncertainty" (such as starting positions in races). Corrupt manipulation (such as doping for improved "skill" and bribery to ensure better starting/finishing positions) is often found in the athletic (rather than governance) realm. However, given that SGBs manage large-scale sporting events, this impacts governance. Some $A B C$ policies of this nature exist (see ICC, 2014), and there are suggestions for more (Maennig, 2016, Carpenter, 2016), but the deontological constraints, where rules are "narrowly framed and directed" (McNamee, 1998), may impact effectiveness in practice. 
Similarly, in accounting, action controls are used in business to ensure that employees behave in line with organisational values (see Luft, 2016). So, while rules are necessary as a standard against which to hold those in governance to account, the rules and context themselves affect usefulness and success. This is because, amongst other things, judgement is required to apply them (Reddiford, 1998).

The commodification of sport can be deemed ethically undesirable if it supersedes internal moral values that sport should propagate (Walsh and Giulianotti, 2007). This highlights the need for diversity in stakeholder opinions in both decision-making and accountability processes. These stakeholders are subject to professional ethics and codes. The latter tend to focus on integrity (De Waegeneer et al., 2016), and the types of bribery stakeholders engage in make an argument for applying rules-based ethics, where what is (or not) considered bribery is clearly set out for the officer/agent/stakeholder. However, organisational desire for change, and involvement of stakeholders and governance officials make codes more effective (De Waegeneer et al., 2017). This, in turn, suggests specific $A B C$ guidance is needed for all stakeholders in sport. However, the emergence of loopholes is an inevitable by-product of rules-based guidance, requiring constant maintenance and update once implemented.

\section{Criminology}

Criminological perspectives on financial corruption focus on prevention and control (Brooks, 2016), while the more sociological literature often deals with the institutionalisation of corrupt culture (Ashforth and Anand, 2003, Gabbioneta et al., 2013). Both are invariably concerned with human behaviour and, in particular, motivation to engage in corruption.

Prevention begins with understanding why corruption occurs and targeting enabling factors. Cressey's fraud triangle combines pressure (as an incentive), opportunity (to commit fraud), and rationalisation (of the perpetrator's own actions) to explain what motivates individuals to commit 
fraud (Albrecht et al., 2018). Caution is needed when applying this to some types of fraud (Schuchter and Levi, 2016), and therefore this may not necessarily apply to financial corruption in general, or sport governance bribery in particular. The fraud triangle hypothesis was refined by Wolfe and Hermanson (2004) adding the concept of capability (personal abilities). Fraud triangle elements have influenced international auditing standards and are influenced by corporate culture (Schuchter and Levi, 2016).

Prevention also concerns how corruption is initiated. The culture (shared values and beliefs) of corruption in an organisation affects its employees' propensity to engage in corruption, as culture involves social networks. Human relationships do not play out in a vacuum, and sport, with its emphasis on competition, requires interaction between many stakeholders. Button et al. (2018) drew on resident pathogen theory (where organisational culture and controls lead to issues, in this case, corruption) to explain corruption of susceptible individuals, including "profiling, grooming, financial incentives and coercion". While the research focuses on general corruption and is limited by a small sample size, the idea is applicable to sport for the reasons outlined in the sport industry section. Results are in line with social bonding theory, where the strength of relationships between (unethical) corporate employees may increase propensity to commit financial crime (Gottschalk, 2010).

Company performance is affected by "local bribery environments", including interaction with (public sector) officials (Hanousek and Kochanova, 2016). This is supported by findings by Dong, Dulleck, and Torgler (2012), where willingness to be corrupt depends on levels of perceived corruption in a society: citizens begin to justify their actions in relation to other individuals in their societal space. This also has implications for motivational theories of fraud. Anand, Ashforth, and Joshi (2005) suggest socialisation tactics can be used as $A B C$ through using organisational culture to prevent 
corruption. Thus, a further avenue for sport governance corruption research is testing whether this applies to SGBs.

Walsh and Giulianotti (2007) note that "pursuing sport-for-sport's sake (i.e. regarding sport as intrinsically valuable) realises goods that are intrinsically valuable", and so becomes a motivating factor for individuals linked to these "goods". This closely resembles American Dream theory as applied to corporate fraud which posits that the pursuit of monetary success is the main motivating factor (Choo and Tan, 2007). The issue with such theories of motivation is that they imply value is the ultimate driver for all, but this cannot account for cases where individuals prefer to coach their national side or favourite club over a better-paying job elsewhere.

The control element of the criminology school is affected by cultural attitudes, which can be subjective. For example, a study by Pitt and Abratt (1986) found that perceptions of "wrongness" (whether it classifies as a bribe) associated with a gift depends on both its size and the circumstances of receipt. This in turn creates difficulties for ISGBs forming rules that need to apply to all their members, as a degree of cultural sensitivity and education is required to ensure all members understand the context and definitions as intended.

\section{Enforcement and law}

Pozsgai-Alvarez (2018) postulated that ABC comes in two dimensions: "basic and universal" and "local and specific". This is how both the enforcement and commercial approaches to ABC deal with corruption. In line with this, a KPMG International's (2015) global ABC survey found that "International companies must ... create a strategy of compliance that ... takes account of national differences in regulation". The survey highlights difficulties associated with global codes or policies for multinational organisations like ISGBs. 
$A B C$ laws have existed since ancient times, with specific anti-bribery laws enacted in both ancient Greece (Taylor, 2018) and Rome (Arena, 2018). This progressed to countries enacting ABC laws with increasingly international scope and enforcement. The globalised nature and international reach of Western sports (McNamee and Fleming, 2007) makes SGBs and ISGBs subject to legislation from around the world. For example, the US FCPA $(1977, \S 78 d d-3)$ has provisions that prohibit giving/offering/promising anything of value, directly or indirectly, to a foreign or party official or candidate intending to gain or retain improper business advantages. The Act also prohibits corrupt payments through intermediaries or third parties (such as agents) where knowledge exists. As previously discussed, sports organisations are not, generally, public sector bodies, and their officials are therefore not classed as public sector officials. However, other legislation and regulation can be (and has been) used by the US in combatting corruption, as was the case with the conviction of FIFA officials (US DOJ, 2017) under the Racketeer Influenced and Corrupt Organizations Act in the US (Wragge and Trusty, 2018, 15:51-16:08).

Another piece of legislation with potentially global reach is the UK Bribery Act 2010, whose broader definition of bribery (noted previously) includes private sector bribery, both passive (receiving) and active (offering) bribery, and facilitating payments, with a specific carve-out for the latter in the FCPA (US DOJ and SEC, 2012, Baughn et al., 2010). Facilitating payments are those made to (usually public sector) officials to encourage actual, faster, or more efficient job performance in that element relating to the payee's business, like a customs official requesting bribes to release legal goods.

Facilitating payments may be defined in the legal sphere with the same public-sector bias as other corruption terms, but can be applied to the private-sector case of sport. SGBs and ISGBs can face facilitating payment situations during event management, procurement, fund allocation decisions, and sponsorship and/or broadcast rights negotiations. 
There are two distinct (though not mutually exclusive) methods for classifying government and organisational approaches to combatting corruption (Croall, 2004). Crime control, the deterrent approach, focuses on prosecuting and punishing offenders. This has the advantage of precedent, with most legal enforcement frameworks following this approach. In contrast, regulation is a discretionary enforcement style based on cooperation and self-regulation (although this can also be non-voluntary, as in the case of certain financial regulation imposed on financial institutions, such as MiFiD II). It has the advantage of being cheaper (unless criminal sanctions are imposed) and is the $A B C$ approach usually applied to SGBs and ISGBs.

A mix of crime control and regulatory approaches is often the most effective strategy in combatting financial crime and market failure (Croall, 2004). This approach is taken by some UK regulators (such as the FCA), where the self-regulated approach (in applying the UK Corporate Governance Code (Mallin, 2016)) is supplemented by heavy fines for non-compliance with regulations.

There is also literature on ABC policy perspectives. Abbink (2004) uses an experimental game to show staff rotation decreases propensity to pay bribes. Abbink likens the Olympic Games venue allocation bribery scandals to "one-shot" environments, where staff rotation would not be effective. This implies that staff rotation should not be the sole $A B C$ policy in place.

Another mechanism is whistleblowing hotlines. Abbink and Wu (2017) find that rewarding whistleblowers decreases likelihood of bribery, albeit in an experimental game using Chinese students. There is precedent for this method in law. One example is Floyd Landis being awarded $\$ 1.1$ million for whistleblowing on Lance Armstrong's doping in cycling under the US False Claims Act (Cassin, 2018). Whistleblowing is increasingly the focus of international laws. For example, after a public campaign by Transparency International, the Italian Senate approved Law 179/2017, 
strengthening the position of whistleblowers, although they did not introduce financial incentives (Sillaman and Bernardi, 2018).

Issues with introducing whistleblowing policies in organisations include protectionist cultures creating potential whistleblower reluctance to come forward, and the bystander effect (Latané and Darley), where everyone assumes someone else has blown the whistle (Cottrell and Erickson, 2018). For an example of poor culture, FIFA's former president, Sepp Blatter, stated in an interview: "Because if you are a whistleblower, it's not correct as well..." (Conn, 2018).

\section{Commercial perspectives}

Commercial bribery is often defined as business to business bribery (Button et al., 2018), although bribery of individuals and third party representatives (such as sports agents or financial intermediaries) can also form part of trade-related corruption.

Bribery is a significant risk to business and corporate governance (Transparency International, 2016, Klitgaard, 1988), including from costs, fines, and reputational damage arising from, amongst other elements, agency costs. It is also a growing risk area from an organisational compliance perspective, because of extensive legislation and global enforcement co-operation in place to reduce and prevent bribery.

Bray's (2007) study shows corruption's (negative) effect on business transactions. Transparency International's (2011) Bribe Payers Index charts likelihood of winning business contracts abroad by paying bribes. These studies give a flavour of problems associated with bribery from a business perspective. However, the main limitation to these (and others of their kind) is that their basis of measurement is perception and not quantity (Brooks et al., 2013, Sampford, 2006). Corruption is hard to measure because it is not tangible or openly discussed by perpetrators. Trace International's 
(Trace International Inc, 2018)Bribery Risk Matrix assesses risk of bribery in countries, based on indicators and indices compiled by the UN and the World Bank, amongst others (Di Palma, 2017). However, perception can be a useful and valid proxy where alternatives are scarce, and empirical testing is limited by lack of data availability.

\section{Corporate governance}

Adams (2003) posited that international corporate governance consists of three elements: risk management, due diligence, and compliance. The latter two have been covered, so it is on the former that this section concentrates: an organisation's structure at the management level to minimise risk of bribery. Agency and stewardship theories can both aid prediction of potential risk areas, such as those arising from information asymmetry (between governing officials and stakeholders) or those from overfamiliarity (between SGB officials and/or sponsors or agents). This is supported by Bruinsma and Bernasco (2004), who use social network theory to show how illegal organisations differ in their structure in response to risk, and the research of Booth et al. (2015), discussed below.

Given the principle of autonomy, and ISGB history of organic growth as amateur associations before becoming the (albeit usually non-profit) corporate giants of today (Pielke, 2016, Smith and Stewart, 2010), it is perhaps unsurprising that ISGBs have a different approach to corporate governance compared to other charitable or corporate organisations. Morgan (2002) identified four different types of governance in professional sport:

- hierarchy (where key decisions are made by a sport's national or international governing body),

- cartel (such as the franchise model found in the NFL and NBA),

- oligarchy (such as the case of English football, with the Football Association and the Premier League being responsible for different elements of league management), and 
- promoter-led (as found in boxing).

Not all these models are relevant here as SGBs and ISGBs tend to follow a hierarchy model. However, league governance structure may affect the power distribution between leagues and SGBs (Morgan, 2002, Smith and Stewart, 2010), which in turn may affect governance and ABC policy. For example, both Formula 1 (FIA, 2017, Article 14.1-2) and the NBA (FIBA, 2014, Article 15.1.2) enjoy decision-making representation within their ISGB.

Chappelet (2016b) sets out a classification matrix for sporting bodies involved in governance, charting members (natural persons versus legal organisations) against benefits accruing from membership (modest versus substantial). While useful for classifying sporting bodies, the need to comply with basic governance exists regardless of structure. Thus, $A B C$ is applicable for all those bodies covered in the matrix.

Booth et al. (2015), in their review of sport governance structures, conclude that sport is not a corporate governance "special case". They find increased demand for accountability as organisations commercialise can result in governance structure changes, as was the case with Swimming Australia's incorporation to facilitate negotiation of TV rights contracts. This is in line with findings of Kikulis, Slack and Hinings (1995) of a trend towards more professional governing boards in sport, although there is also lack of appetite for volunteers ceding control to professional staff. Sport organisations do not always have resources to perform the more professional roles found in similar organisations in other industries (Ferkins et al., 2005). However, it may be hard to apply that argument to some of the larger, high-revenue SGBs and ISGBs.

Monitoring (including auditing and compliance) is an important control (Lipicer and Lajh, 2013) that ensures resources are correctly allocated. McNamee and Fleming (2007) advocate the use of ethics 
audits to ensure that SGBs comply with their own stated values. Monitoring compliance with both principles and rules-based policies is therefore another element of $A B C$ incorporated in the framework.

There are limited sport governance codes setting out best practice within the boundaries of autonomy and voluntary organisational status (Australian Sports Commission, 2012, Sport New Zealand, 2009, EU Expert Group on Good Governance, 2013), but there is no universal one (Geeraert et al., 2014). Most codes are principles-based (broad, flexible guidelines), making litigation in areas such as duty of care breaches less likely (as breach is easier to prove where rigid rules exist). It also means they do not offer clear, practical rules. Other codes concentrate on general corporate governance procedures, such as A Code for Sport Governance (Sport England and UK Sport, 2016), based on the UK Corporate Governance Code (Financial Reporting Council, 2016). These, while useful for promoting good governance, do not fully embrace anti-bribery.

The dominance of Europeans as senior officers of ISGBs, combined with ISGBs' ability to indulge in regulatory arbitrage for their operations (Geeraert et al., 2014, Geeraert et al., 2013) reinforces the principle of autonomy over laws, rules, disputes, and relationships within their specific sport recognised by governments and other external bodies (Forster, 2006, Forster and Pope, 2004). To counter autonomy issues, some political bodies have set best practice or required sport governance codes for sports organisations wishing to obtain government funding (Australian Sports Commission, 2015, Sport England and UK Sport, 2016).

Furthermore, autonomy and the unique structure of SGBs are used to question applicability of traditional corporate governance mechanisms and policies, including $A B C$. Governance structures differ from traditional executive models, especially with regards independence and accountability, which affects propensity for bribery (in line with the politics literature), especially when many 
governance officials are naïve or purposefully ignorant of existing corruption (Brooks et al., 2013, Kirkeby, 2016).

Some solutions to the governance problems include sharing best practice by SGBs (such as Netball New Zealand) and ISGBs (such as the Badminton World Federation) (Pedersen, 2016) to encourage strong control systems. Creating best practice codes for SGBs is another potential solution (Michie and Oughton, 2005, Pielke, 2016). Further suggestions include reporting on pre-agreed governance measures (including transparency and compliance) or benchmarking (Chappelet and Mrkonjic, 2013, Carpenter, 2016, Geeraert, 2016) to encourage external monitoring by stakeholders.

In line with Klitgaard's (1988) formula, and Rose-Ackerman's (1999) and Jain's (2001) frameworks for corruption, transparency and accountability are targeted by researchers and policy-makers alike for their importance in the $A B C$ sphere (Mallin, 2016). Improving transparency and disclosure in including public communication, conflict of interest, executive pay, and procurement (Pielke, 2016, Geeraert, 2016, Maennig, 2016, Menary, 2016) negatively affect corruption. Improving accountability covers such areas as explanations of democratic processes, availability of whistleblowing hotlines or reporting mechanisms, audit trails for receipt and use of funds, and so on (see lonescu, 2015, Pielke, 2016, Geeraert, 2015). Financial accountability in particular is one where the accounting field could help inform improvements to current sport governance practice.

\section{Anti-bribery framework and $A B C$ implications}

The literature review conducted in this paper discussed key disciplines in corruption and bribery research as applicable to sport governance. This section amalgamates the interdisciplinary studies above into a framework. The anti-bribery framework should enable critical assessment of bribery and $A B C$, as well as offer applications for $A B C$ policies grounded in theory, as illustrated in Figure 1. 
Given the sport industry's corporate credentials, current public sector corruption literature is adapted to cover private- or quasi-private sector SGBs and ISGBs. The main interdisciplinary corruption literature covered in this paper includes perspectives from:

- politics, which argues for inclusion of economic rents, discretionary powers, enforcement powers, stability, and accountability in any assessment of corruption;

- economics, which shows limiting interactions between members helps reduce corruption (such as independence and segregation of duties) and that transparent online reporting reduces bribes (particularly important in relation to whistleblowing);

- ethics, where the role of epistemological uncertainty in competition has implications for $A B C$ focused on match-fixing, while the debate surrounding commodification and autonomy has implications for sponsorship and other stakeholder ABC policy-makers;

- criminology, where dealing with motive and opportunity, as well as culture, helps inform the $A B C$ control debate;

- global enforcement and law, where the international nature of sports means compliance with $A B C$ is tougher, especially around gifts and entertainment, facilitating payments, and whistleblowing;

- the commercial sphere, where negative effects on profit and difficulties monitoring bribery influences success of $A B C$ implementation; and

- corporate governance, where commercialisation affects governance structures, although ceding control to professionals faces resistance that needs to be assessed in a financial corruption context, as well as making the case for risk management and monitoring to control against corruption.

These perspectives highlight key areas of overlap in the research areas and findings. The importance of definitions was highlighted in a number of disciplines, including economics, criminology, enforcement, law, and the commercial arena. This clarification of concepts is therefore the first step 
required in a theoretical framework, as illustrated in the diagrammatical depiction of the antibribery framework in Figure 2.

Figure 2: Theoretical framework for bribery and $A B C$

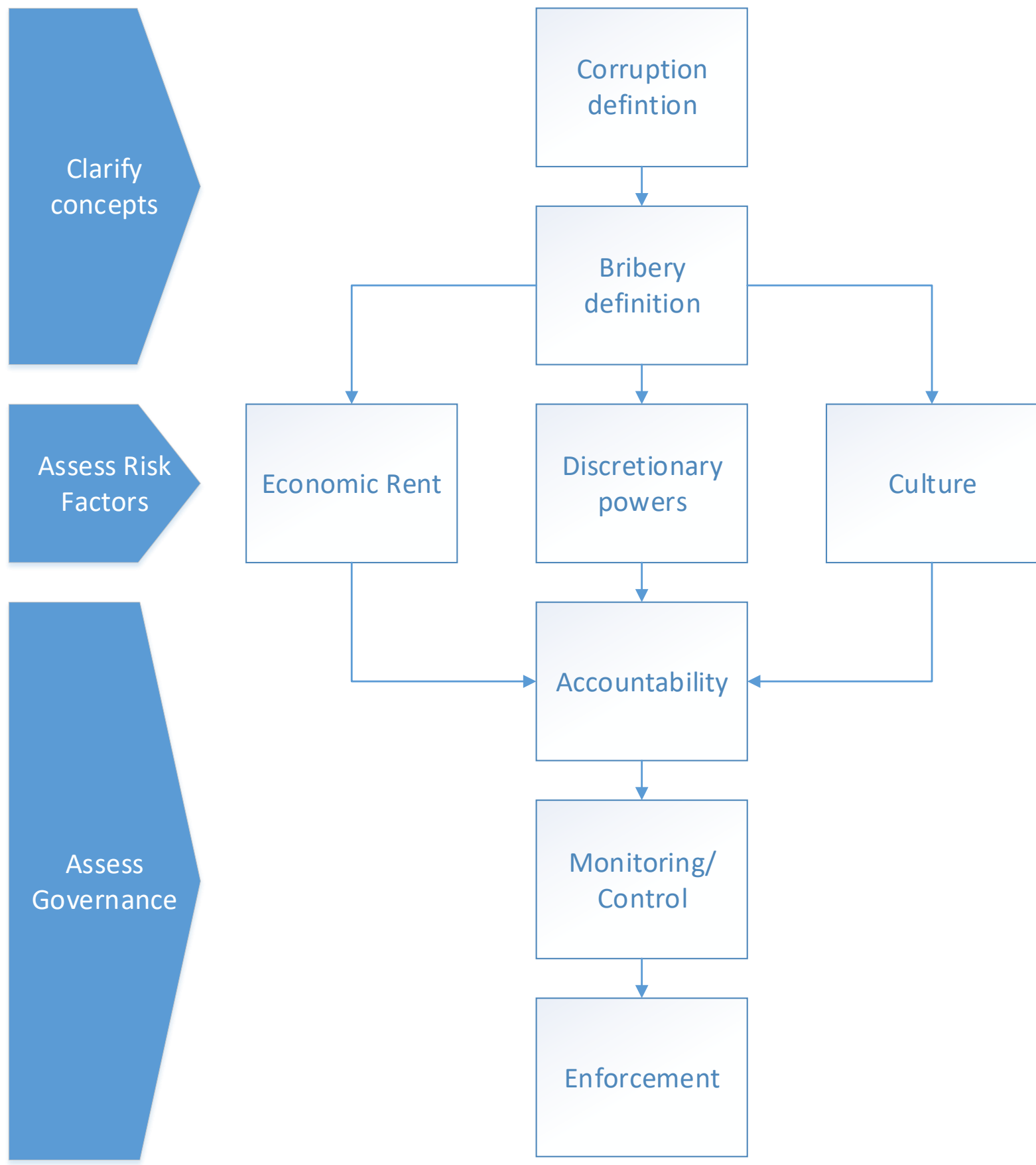

As previously discussed, the terms corruption (Ashforth and Anand, 2003, Caiden, 2001, Masters, 2015, Quiñones, 2000, Rose, 2017, Den Nieuwenboer and Kaptein, 2008) and bribery (Transparency 
International, 2017a, US DOJ and SEC, 2012) have multiple definitions. Thus, the term "corruption" needs to be defined first, as bribery is its subset (Transparency International, 2017b, ICAEW, 2017), and therefore cannot be reasonably defined if the parameters of (financial) corruption have not been previously set.

The literature discussed in this paper shows the definition requires consideration over inclusion of:

- $\quad$ private (as well as public) sector corruption;

- different types of corruption (as set out in Table 1);

- corruption involving underperformance (Gorse and Chadwick, 2010); and

- jurisdictions (single country versus global considerations).

The second clarification process, defining bribery, would require a consideration of whether or not the following are covered:

- facilitation payments (as per enforcement and law);

- unactioned bribery (as per the bribery section);

- both giving and receiving bribes;

- organisational (Den Nieuwenboer and Kaptein, 2008, Ashforth and Anand, 2003) as well as private gain of the briber;

- public gain, or noble cause corruption (Caiden, 2001, as cited in Masters, 2015) resulting from the bribe.

The next step in the framework is to assess the risk factors for bribery. This is in line with politics (and economics) literature on the causes of corruption (Jain, 2001, Klitgaard, 1988, Rose-Ackerman, 1999), which focus on economic rents and discretionary powers as two of the main elements. Other factors linked to corruption include lack of transparency (Pielke, 2016, Geeraert, 2016, Maennig, 
2016, Menary, 2016) and instability (Rose-Ackerman, 1999), contained within the concept of "culture".

Economic rent in SGBs and ISGBs is linked to autonomy (Breivik, 2000, Chappelet, 2016a), where sport's special status allows for oligopolistic and monopolistic sport league structures (Walsh and Giulianotti, 2007) and the high(er) profits and economic rents that theoretically follow. There is also input from the ethics and corporate governance literature on commodification of sport (Smith and Stewart, 2010, Beech and Chadwick, 2013, Gorse and Chadwick, 2010) and its effects on sport governance (Barker, 2013, Szymanski and Kuypers, 2000, Booth et al., 2015), which has implications for the social versus financial role of sport debate. The latter shares elements with corporate governance literature on non-profit organisational governance and corporate social responsibility (Carroll, 1979, Rodgers et al., 2015).

Discretionary powers for decision-makers is another cause of corruption (Jain, 2001, Klitgaard, 1988, Rose-Ackerman, 1999). The requirement for judgement is affected by values, as per the ethics literature (Reddiford, 1998). Agency and stewardship theory research from both corporate governance and economics realms inform the need for governance assessment (the next step in the framework), particularly accountability. Discretionary powers are also affected by criminological enabling factors (Albrecht et al., 2018, Schuchter and Levi, 2016, Wolfe and Hermanson, 2004) and the crime control versus regulatory approach debate (Croall, 2004) with regards governance.

Culture is a risk factor for corruption, as poor values can be propagated through employee or officer conduct. Criminology literature assesses effects on corruption in both country (Dong et al., 2012, Hanousek and Kochanova, 2016) and organisational attitude (Button et al., 2018, Gottschalk, 2010) effects on corruption. Socialisation can also be used as an ABC measure (Anand et al., 2005), although the ethics literature around contextualisation of values and norms with regards the 
competitive nature of the sport (Skillen, 1998) does present a barrier that needs to be accounted for and overcome. Enforcement perspectives also refer to the "local and specific" nature of ABC (Pozsgai-Alvarez, 2018), in line with literature on need for societal knowledge in bridging the autonomy/norms ethical divide (Steidlmeier, 1999).

The governance assessment section of the framework relates to accountability, monitoring and control, and enforcement. Lack of accountability as a cause of corruption is well-documented in the politics and economics literature (Klitgaard, 1988, Klitgaard, 1998, Rose-Ackerman, 1999, Nichols, 2012), and from commercial perspectives (Bray, 2007, Di Palma, 2017). The corporate governance literature focus is on transparency, conflict of interest, procurement, and other financial compliance issues that affect governance (Pielke, 2016, Geeraert, 2016, Maennig, 2016, Menary, 2016).

Accountability is strongly dependent on monitoring and control (Cooper and Johnston, 2012) to ensure that the governance of a sporting organisation continues to function with integrity (Lipicer and Lajh, 2013). Agency and stakeholder theories, in combination with the diversity of stakeholders in SGBs and ISGBs, advocates for monitoring and control. Staff rotation (Abbink, 2004), online reporting (Ryvkin et al., 2017), ethics audits (McNamee and Fleming, 2007), and whistleblowing procedures (Erickson et al., 2017, Lambsdorff and Frank, 2010) all form part of the internal control system.

Enforcement of policies and procedures, and thus governance and ethical compliance, is the final element of the framework. Monitoring and control of breaches is of limited use if punishments are not enforced (Jain, 2001, Nichols, 2012). The need for compliance action (or perceived action) is intertwined with cultural elements previously discussed. The method of enforcement (rules-based or principles-based) may thus factor into the effectiveness of ABC policy. 


\section{Direction for further research}

The interdisciplinary nature of the framework (and, indeed, of bribery and other forms of financial corruption in sport) opens it up to further research in a number of areas and disciplines. Empirical evidence in support of the framework and testing of its robustness and effectiveness in both the theoretical framing of bribery and the practical impact on $A B C$ would require a critical analysis of its component elements.

\section{Clarifying concepts}

There is a need for a better understanding of the diversity of definitions of both corruption and bribery both across time and culture (including work smilar to that on corruption undertaken by Rose, 2017), and across locations and jurisdictions. There is also currently no taxonomy of bribery.

\section{Assessing risk factors}

Valuation of the economic rents and other financial rewards would help further assuage the relationship between bribery and profit. There is scope for more research into the effectiveness and practicalities of staff rotation in a sport setting, the effects of discretionary powers on $A B C$, and the effects of societal and organisational culture (including the effects of violence and competition in sport) on bribery.

\section{Assessing governance}

More research into the power elements of accountability (Cooper and Johnston, 2012) and effectiveness of transparency and accountability in reducing bribery would inform the literature, as would the balance of risk and accountability against profit and trade in sport. The effect of monitoring, including ethics audits (McNamee and Fleming, 2007) and whistleblowing hotlines and incentives in sport on profits and $A B C$ (both enforcement and economic perspectives) is an underdeveloped research area. 


\section{Conclusion}

This paper bridges the gap between existing interdisciplinary literature on corruption and its ability to inform the $A B C$ sphere through the anti-bribery framework. This is applied to the case of sport governance, focusing on SGBs and ISGBs.

First, the case is made that the field of sport where SGBs and ISGBs govern is indeed a corporatised industry, and therefore corporate governance and private sector perspectives on corruption are relevant.

The main disciplines in corruption research were then amalgamated into a framework covering the following perspectives:

- politics;

- economics;

- ethics;

- corporate governance;

- criminology;

- global enforcement; and

- commercial ones.

The need for a definition of both corruption and bribery is evident throughout the literature, with a need to ensure comparisons of policies are fair, and assessment of bribery environments are clear on their conceptual coverage. This therefore forms the start of the framework, which requires clarification of concepts covered in an assessment of the bribery environment or the application of $A B C$ initiatives. 
Assessment of risk factors including economic rent, discretionary powers, and culture, which arise from the literature's congruity on the causes of corruption, is supplemented by the cultural implications for corruption highlighted by other disciplines including criminology, ethics, and corporate governance.

The need for accountability, monitoring and control, and enforcement spans the disciplines and informed their inclusion in the governance assessment section of the framework. $A B C$ initiatives in sport and beyond should be considered by policy-makers and other decision-makers in light of this.

While the framework takes a Western viewpoint of bribery (as the definitions are multiple and incongruent), the vast majority of ISGBs are based in Europe, thus giving credence to the use of the above framework in their approach to $A B C$.

There are, of course, also other disciplines to help inform ABC policy in sport governance. Users of the framework, too, need not be limited to bribery (as it can be adapted to other forms of financial corruption) or sport (as it can apply to other industries).

Further research on the application of $A B C$ policies and the effectiveness of an interdisciplinary approach to $A B C$ should be considered in line with the suggestions above. It is in the best interest of all stakeholders that bribery in sport governance is minimised.

\section{References}

1977. Foreign Corrupt Practices Act. United States.

Abbink, K. 2004. Staff rotation as an anti-corruption policy: an experimental study. European Journal of Political Economy, 20, 887-906. 
Abbink, K. \& Wu, K. 2017. Reward self-reporting to deter corruption: An experiment on mitigating collusive bribery. Journal of Economic Behavior and Organization, 133, 256-272.

Adam, G. \& Aiden, S. 2012. Corruption and control: a corruption reduction approach. Journal of Financial Crime, 384.

Adams, M. A. 2003. The three pillars of good governance. Risk Management, 8.

Ades, A. \& Di Tella, R. 1999. Rents, Competition, and Corruption. The American Economic Review, 982.

Agius, M. 2018. Judge overturns not-guilty sentence for two Malta footballers accused of match fixing. Malta Today [Online]. Available: https://www.maltatoday.com.mt/sports/football/84294/judge overturns notguilty senten ce for two malta footballers accused of match fixing\#.WxUfHfkvzlU [Accessed 04/06/2018].

Cricket's Match Fixers, 2018. Directed by Al Jazeera Investigations. Al Jazeera.

Albergotti, R. 2014. Wheelmen: Lance Armstrong, the Tour de France, and the Greatest Sports Conspiracy Ever, Headline.

Albrecht, W. S., Albrecht, C. O., Albrecht, C. C. \& Zimbleman, M. 2018. Fraud examination, Boston, MA, Cengage Learning.

Anand, V., Ashforth, B. E. \& Joshi, M. 2005. Business as usual: The acceptance and perpetuation of corruption in organizations. Academy of Management Executive, 19, 9-23.

Arena, V. 2018. Fighting Corruption: Political Thought and Practice in the Late Roman Republic. In: KROEZE, R., VITORIA, A. \& GELTNER, G. (eds.) Anticorruption in History: From Antiquity to the Modern Era. Oxford: Oxford University Press.

Ashforth, B. E. \& Anand, V. 2003. THE NORMALIZATION OF CORRUPTION IN ORGANIZATIONS. Research in Organizational Behavior, 25, 1-52.

Australian Sports Commission 2012. Sports Governance Principles.

Australian Sports Commission 2015. Mandatory Sports Governance Principles. 
Azfar, O., Lee, Y. \& Swamy, A. 2001. The Causes and Consequences of Corruption. The Annals of the American Academy of Political and Social Science, 42.

Barker, M. 2013. Sports finance. In: BEECH, J. \& CHADWICK, S. (eds.) The Business of Sport Management. London: Pearson Education Limited.

Batchelor, B. 2005a. Introduction: Basketball in America. In: BATCHELOR, B. (ed.) Basketball in America : from the playgrounds to Jordan's game and beyond. Binghamton, N.Y. : Haworth.

Batchelor, B. 2005b. King James: LeBron James, Hype, Hope, and the Future of the NBA. In: BATCHELOR, B. (ed.) Basketball in America : from the playgrounds to Jordan's game and beyond. Binghamton, N.Y. : Haworth.

Baughn, C., Bodie, N., Buchanan, M. \& Bixby, M. 2010. Bribery in International Business Transactions. Journal of Business Ethics, 92, 15-32.

BBC. 2018. Betraying the Game: African officials filmed taking cash. Available: https://www.bbc.co.uk/sport/football/44396127 [Accessed 19/06/2018].

Becker, G. S. 1968. Crime and Punishment: An Economic Approach. Journal of Political Economy, 76, 169.

Beech, J. G. 2013. The internationalisation of sport. In: BEECH, J. G. \& CHADWICK, S. (eds.) The business of sport management. 2nd ed.: Harlow : Financial Times/Prentice Hall.

Beech, J. G. \& Chadwick, S. 2013. Introduction: the commercialisation of sport. In: BEECH, J. G. \& CHADWICK, S. (eds.) The business of sport management. 2nd ed.: Harlow : Financial Times/Prentice Hall.

Blake, H. 2016. Priorities for the UK sport sector and beyond: integrity, transparency and accountability: The role of investigative journalism in protecting clean sport. Sport governance in the UK - priorities for transparency, safe participation and diverse leadership. Westminister Media Forum.

Blake, H. \& Calvert, J. 2015. The ugly game : the Qatari plot to buy the World Cup, London : Simon \& Schuster. 
Blödorn, M. 1988. Das magische Dreieck: Sport-Fernsehen-Kommerz. In: HOFFMANN, W. \& RIEM, W. (eds.) Neue Medienstrukturen - neue Sportberichterstattung. Baden Baden/ Hamburg: Nomos Verlagsgesellschaft.

Booth, R., Gilligan, G., de Zwart, F. \& Gordon-Brown, L. 2015. Generic Models of Sports Governance and Their Potential for Sustainability. In: LEE Y., F. R. (ed.) The Sports Business in The Pacific Rim. Springer, Cham.

Bray, J. 2007. Facing up to corruption 2007: A practical business guide. Control Risks. Simmons \& Simmons.

Breivik, G. 2000. Against chance: a causal theory of winning in sport. In: TÄNNSJÖ, T. \& TAMBURRINI, C. M. (eds.) Values in sport : elitism, nationalism, gender equality and the scientific manufacture of winners. London : E \& FN Spon.

Brooks, G. 2016. Criminology of corruption : theoretical approaches, London : Palgrave Macmillan.

Brooks, G., Aleem, A. \& Button, M. 2013. Fraud, corruption and sport, Basingstoke : Palgrave Macmillan.

Bruinsma, G. \& Bernasco, W. 2004. Criminal groups and transnational illegal markets. Crime, Law \& Social Change, 41, 79.

Bruno, G. 2017. Adidas Executive Indicted in Connection with NCAA Fraud, Bribery Case. TheStreet [Online]. Available: https://www.thestreet.com/story/14383155/1/adidas-executiveindicted-in-connection-with-ncaa-fraud-bribery-case.html [Accessed 09/06/2018].

Buschmann, R. \& Wulzinger, M. 2018. Football Leaks: Uncovering the dirty deals behind the beautiful game, London, Guardian Faber.

Button, M., Shepherd, D. W. J. \& Blackbourn, D. 2018. Co-offending and bribery: the recruitment of participants to corrupt schemes and the implications for prevention. Security Journal.

Caiden, G. E. 2001. Corruption and governance. In: CAIDEN, G. E., DWIVEDI, O. P. \& JABBRA, J. (eds.) Where corruption lives. 
Carpenter, K. 2016. Preventing corruption ahead of major sports events: Learning from the 2012 London Games. In: TRANSPARENCY INTERNATIONAL (ed.) Global Corruption Report: Sport. Abingdon, Oxon: Routledge.

Carroll, A. B. 1979. A three dimensional conceptual model of corporate social responsibility. Academy of Management Review, 4, 497-505.

Cashmore, E. \& Dixon, K. 2016. Corruption. In: CASHMORE, E. \& DIXON, K. (eds.) Studying football. London : Routledge, Taylor \& Francis Group.

Cassin, R. L. 2018. Drug cheat Floyd Landis collects $\$ 1.1$ million for blowing the whistle on Lance Armstrong. The FCPA Blog [Online]. Available:

http://www.fcpablog.com/blog/2018/4/25/drug-cheat-floyd-landis-collects-11-million-forblowing-the.html [Accessed 08/06/2018].

Chadwick, S. 2018. What does FIFA really want out of this World Cup? The Conversation [Online]. Available: https://theconversation.com/what-does-fifa-really-want-out-of-this-world-cup97393 [Accessed 19/06/2018].

Chappelet, J.-L. 2016a. Autonomy and governance: necessary bedfellows in the fight against corruption in sport. In: TRANSPARENCY INTERNATIONAL (ed.) Global Corruption Report: Sport. Abingdon, Oxon Routledge.

Chappelet, J.-L. 2016b. Which governance for which organization? A postface. Sport in Society, 19, 857-859.

Chappelet, J.-L. \& Mrkonjic, M. 2013. Basic Indicators for Better Governance in International Sport (BIBGIS): An assessment tool for international sport governing bodies. Lausanne.

Choo, F. \& Tan, K. 2007. An "American Dream" theory of corporate executive Fraud. Accounting Forum, 31, 203-215.

Clarke, G. R. G. \& Xu, L. C. 2004. Privatization, competition, and corruption: how characteristics of bribe takers and payers affect bribes to utilities. Journal of Public Economics, 88, 2067.

Collings, T. 2001. The Piranha Club: power and influence in Formula One, London, Virgin Books Ltd. 
Collins, T. 2017. Association and rugby football: two codes, one historiography. In: HUGHSON, J., MOORE, K., SPAAIJ, R. F. J. \& MAGUIRE, J. A. (eds.) Routledge handbook of football studies. London : Routledge, Taylor \& Francis Group.

Conn, D. 2018. The Fall of the House of Fifa, London, Yellow Jersey Press.

Cooper, C. \& Johnston, J. 2012. Vulgate accountability: insights from the field of football. Accounting, Auditing \& Accountability Journal, 25, 602-634.

Cottrell, S. \& Erickson, K. 2018. The psychology of doping and whistleblowing in sport with Dr Kelsey Erickson. In: COTTRELL, S. (ed.). Law In Sport.

Council of Europe 2001. European Sport Charter (revised). Brussels.

Council of Europe 2014. Council of Europe Convention on the Manipulation of Sports Competitions.

Council of Europe \& UEFA 2018. Memorandum of Understanding between the COuncil of Euope and the Union of European Football Associations (UEFA).

Croall, H. 2004. Combating financial crime: regulatory versus crime control approaches. Journal of Financial Crime, 45.

Daly, M. \& Oliver, J. 2016. Sebastian Coe helped to IAAF presidency by 'corrupt' official [Online]. http://www.bbc.co.uk/sport/athletics/36541301: BBC. [Accessed 21/06/16 2016].

De Sanctis, F. M. 2014. Football, gambling, and money laundering: A global criminal justice perspective, Springer International Publishing.

De Speville, B. 2012. A Review of the Anticorruption Arrangements of the International Cricket Council. ICC.

De Waegeneer, E., Devisch, I. \& Willem, A. 2017. Ethical Codes in Sports Organizations: An Empirical Study on Determinants of Effectiveness. Ethics \& Behavior, 27, 261-282.

De Waegeneer, E., Van De Sompele, J. \& Willem, A. 2016. Ethical codes in sports organizations: Classification framework, content analysis, and the influence of content on code effectiveness. Journal of Business Ethics, 136, 587-598.

Deloitte 2018. Annual Review of Football Finance 2018. In: LLP, D. (ed.). London. 
Den Nieuwenboer, N. A. \& Kaptein, M. 2008. Spiraling down into Corruption: A Dynamic Analysis of the Social Identity Processes That Cause Corruption in Organizations to Grow. Journal of Business Ethics, 133.

Di Palma, V. 2017. Resource Alert: The TRACE Bribery Risk Matrix. FCPA blog [Online]. Available: http://www.fcpablog.com/blog/2017/10/12/resource-alert-the-trace-bribery-riskmatrix.html [Accessed 19/06/2018].

Dong, B., Dulleck, U. \& Torgler, B. 2012. Conditional corruption. Journal of Economic Psychology, 33, 609-627.

Erickson, K., Backhouse, S. H. \& Carless, D. 2017. "I don't know if I would report them": Studentathletes' thoughts, feelings and anticipated behaviours on blowing the whistle on doping in sport. Psychology of Sport \& Exercise, 30, 45-54.

EU Expert Group on Good Governance 2013. Principles of good governance in sport.

European Commission 2007. White Paper on Sport. In: EUROPEAN COMMISSION (ed.). Brussels.

European Parliament 2011. WRITTEN DECLARATION pursuant to Rule 123 of the Rules of Procedure on combating corruption in European Sport.

European Parliament 2012. European Parliament resolution of 2 February 2012 on the European dimension in sport.

Ferguson, N. 2016. Sports Scandals: True stories of cheating, corruption and greed, Chichester, UK, Summersdale Publishers Ltd.

Ferkins, L., Shilbury, D. \& McDonald, G. 2005. The Role of the Board in Building Strategic Capability: Towards an Integrated Model of Sport Governance Research. Sport Management Review, 8, $195-225$.

FIA 2017. FIA Statutes. Geneva: Federation Internationale De L'Automobile.

FIBA 2014. FIBA General Statutes. Mies, Switzerland: Federation Internationale de Basketball. FIFA 2017. Financial Report 2016. Zurich: FIFA.

FIH 2016. Statutes. International Hockey Federation. 
Financial Reporting Council 2016. The UK Corporate Governance Code.

FIS. 2018. Inside FIS - About FIS [Online]. Available: http://www.fis-ski.com/inside-fis/about/by-thepresident/index.html [Accessed 21/06/2018.

Fisher, J. 2005. Elgin Baylor: The First Modern Professional Basketball Player. In: BATCHELOR, B. (ed.) Basketball in America : from the playgrounds to Jordan's game and beyond. Binghamton, N.Y. : Haworth.

Fisman, R. \& Golden, M. A. 2017. Corruption, New York, NY, Oxford University Press.

Forster, J. 2006. Global sports organisations and their governance. Corporate Governance, 6, 72-83.

Forster, J. \& Pope, N. 2004. The political economy of global sporting organisations, London; New York : Routledge.

Fountain, C. 2016. The Betrayal: The 1919 World Series and the birth of modern baseball, New York, Oxford University Press.

The Dallas Cowboys, 2018. Directed by Furman, S., Jackson, J., Riley, T. \& Trout, S.: Amazon Video Limited.

Gabbioneta, C., Greenwood, R., Mazzola, P. \& Minoja, M. 2013. The influence of the institutional context on corporate illegality. Accounting, Organizations and Society, 38, 484-504.

Garcia, B. 2017. Football and Governance. In: HUGHSON, J., MOORE, K., SPAAIJ, R. F. J. \& MAGUIRE, J. A. (eds.) Routledge handbook of football studies. London : Routledge, Taylor \& Francis Group.

Garcia, M. J. \& Norbely, C. 2014. Report on the Inquiry into the 2018/2022 FIFA World Cup Bidding Process. FIFA.

Gardiner, S., Robinson, S. \& Parry, J. 2017. Integrity and the corruption debate in sport: where is the integrity? European Sport Management Quarterly, 17, 6-23.

Geeraert, A. 2015. Sports Governance Observer 2015: The legitimacy crisis in international sports governance. Play the Game. 
Geeraert, A. 2016. Indicators and benchmarking tools for sports governance. In: TRANSPARENCY INTERNATIONAL (ed.) Global Corruption Report: Sport. Abingdon, Oxon: Routledge.

Geeraert, A., Alm, J. \& Groll, M. 2013. Good governance in International Non-Governmental Sport Organisations: an empirical study on accountability, participation and executive body members in Sport Governing Bodies. 8th Annual Conference of the Association for the Study of Sport and the European Union. Istanbul.

Geeraert, A., Alm, J. \& Groll, M. 2014. Good governance in international sport organizations: an analysis of the 35 Olympic sport governing bodies. International Journal of Sport Policy, 6 , 281.

Gorse, S. \& Chadwick, S. 2010. Conceptualising corruption in sport: Implications for sponsorship programmes. The European Business Review, July/August.

Gottschalk, P. 2010. Theories of financial crime. Journal of Financial Crime, 210.

Goudie, A. W. \& Stasavage, D. 1998. A framework for the analysis of corruption. Crime, Law \& Social Change, 29, 113-159.

Graycar, A. 2015. Corruption: Classification and analysis. Policy and Society, 34, 87-96.

Groeneveld, M. 2009. European Sport Governance, Citizens, And The State. Public Management Review, 11, 421-440.

Groothuis, P. A., Johnson, B. K. \& Whitehead, J. C. 2004. Public Funding of Professional Sports Stadiums: Public Choice or Civic Pride? Eastern Economic Journal, 30, 515-526.

Gross, J. 2018. Greg Hardy fight highlights MMA's troubling history of violence outside the octagon. The Guardian [Online]. Available: https://www.theguardian.com/sport/2018/jun/12/greghardy-mma-ufc-domestic-violenceallegations?utm source=esp\&utm medium=Email\&utm campaign=Australian+sports\&utm term=277887\&subid=19613276\&CMP=ema aus spt [Accessed 19/06/2018].

Hamilton, T. \& Coyle, D. 2013. The Secret Race: Inside the Hidden World of the Tour de France, London, Bantam Press. 
Hanousek, J. \& Kochanova, A. 2016. Bribery environments and firm performance: Evidence from CEE countries. European Journal of Political Economy, 43, 14-28.

Hill, D. 2010. A critical mass of corruption: why some football leagues have more match-fixing than others. INTERNATIONAL JOURNAL OF SPORTS MARKETING \& SPONSORSHIP, 11, 221-235. Howman, D. 2013. SUPPORTING THE INTEGRITY OF SPORT AND COMBATING CORRUPTION. Huggins, M. 2017. Football and Gambling. In: HUGHSON, J., MOORE, K., SPAAIJ, R. F. J. \& MAGUIRE, J. A. (eds.) Routledge handbook of football studies. London : Routledge, Taylor \& Francis Group.

Hughes, A. 2018. Why some Western companies are distancing themselves from the World Cup brand. The Conversation [Online]. Available: https://theconversation.com/why-somewestern-companies-are-distancing-themselves-from-the-world-cup-brand-96989 [Accessed 19/06/2018].

Hughson, J. 2017. FIFA and the World Cup. In: HUGHSON, J., MOORE, K., SPAAIJ, R. F. J. \& MAGUIRE, J. A. (eds.) Routledge handbook of football studies. London : Routledge, Taylor \& Francis Group.

IAAF 2015. Code of Ethics. Monaco: IAAF.

ICAEW. 2017. Bribery and Corruption [Online]. ICAEW.com. Available:

http://www.icaew.com/en/technical/legal-and-regulatory/business-crime-andmisconduct/bribery-and-corruption [Accessed 06/12/2017.

ICC 2014. Code of Ethics of the ICC. Dubai: The International Cricket Council.

ICC 2017. ICC Annual Report 2016-2017. Dubai: The International Cricket Council.

IGF 2016. IGF Betting and Anti-Corruption Policy. Lausanne, Switzerland: International Golf Federation.

Interpol. 2018. Crimes in sport [Online]. Available: https://www.interpol.int/Crime-areas/Crimes-insport/Integrity-in-sport [Accessed 04/06/2018. 
Ionescu, L. 2015. The Economics of Corruption in Professional Sport. Economics, Management, and Financial Markets, 10, 109-114.

Jain, A. K. 2001. Corruption: A Review. Journal of Economic Surveys, 15, 71-121.

Kikulis, L. M., Slack, T. \& Hinings, B. Does Decision Making Make a Difference? Patterns of Change Within Canadian National Sport Organizations. 19951995 United States. HUMAN KINETICS PUBLISHERS, 273.

Death of a Gentleman, 2015. Directed by Kimber, J., Collins, S. \& Blank, J.

Kirkeby, M. 2016. Challenges and approaches to ensuring good governance in grassroots sport. In: TRANSPARENCY INTERNATIONAL (ed.) Global Corruption Report: Sport. Abingdon, Oxon Routledge.

Klitgaard, R. 1988. Controlling corruption, Berkeley, Calif ; London : University of California.

Klitgaard, R. 1998. Combating Corruption. UN Chronicle, 35, 90.

Kohe, G. Z. 2017. The Football Trust as a mechanism of industry change. In: HUGHSON, J., MOORE, K., SPAAIJ, R. F. J. \& MAGUIRE, J. A. (eds.) Routledge handbook of football studies. London: Routledge, Taylor \& Francis Group.

KPMG International 2015. Anti-Bribery and Corruption: Rising to the challenge in the age of globalization.

Kunkel, T., Doyle, J. P., Funk, D. C., Du, J. \& McDonald, H. 2016. The Development and Change of Brand Associations and Their Influence on Team Loyalty Over Time. Journal of Sport Management, 30, 117-134.

Kyprianou, A. 2015. A WORLD AGAINST CORRUPTION; MATCH FIXING. International Sports Law Review Pandektis, 11, 522-525.

Lambert-Mogiliansky, A. 2002. Why firms pay occasional bribes: the connection economy. European Journal of Political Economy, 18, 47-60.

Lambsdorff, J. G. \& Frank, B. 2010. Bribing versus gift-giving - An experiment. Journal of Economic Psychology, 31, 347-357. 
Lambsdorff, J. G. \& Frank, B. 2011. Corrupt reciprocity - Experimental evidence on a men's game. International Review of Law \& Economics, 31, 116-125.

Latané, B. \& Darley, J. M. The unresponsive bystander : why doesn't he help?, New York : AppletonCentury-Crofts.

Le Blond, J. 2014. Bernie Ecclestone: 'I'm an idiot' for paying $f 60 m$ to settle F1 bribery trial. The Guardian [Online]. Available: https://www.theguardian.com/sport/2014/aug/05/formulaone-bernie-ecclestone-idiot-paying-100m-dollars-settle-bribery-trial [Accessed 18/05/2018].

Lipicer, S. K. \& Lajh, D. 2013. Monitoring systems of governance in sport: Looking for best practices from the European Union and beyond. Kinesiologia Slovenica, 19, 43-59.

Lipton, M. \& Lorsch, J. W. 1992. A Modest Proposal for Improved Corporate Governance. The Business Lawyer, 59.

Lord Woolf \& PricewaterhouseCoopers 2012. An independent governance review of the International Cricket Council. ICC.

Luft, J. 2016. Cooperation and competition among employees: Experimental evidence on the role of management control systems. Management Accounting Research, 31, 75-85.

Maennig, W. 2005. Corruption in International Sports and Sport Management: Forms, Tendencies, Extent and Countermeasures. European Sport Management Quarterly, 5, 187-225.

Maennig, W. 2016. Preventing corruption in the planning of major sporting events: open issues. In: TRANSPARENCY INTERNATIONAL (ed.) Global Corruption Report: Sport. Abingdon, Oxon: Routledge.

Malagueño, R., Albrecht, C., Ainge, C. \& Stephens, N. 2010. Accounting and corruption: a crosscountry analysis. Journal of Money Laundering Control, 13, 372-393.

Mallin, C. A. 2016. Corporate governance, Oxford, United Kingdom : Oxford University Press, Fifth edition.

Manoli, A. E. \& Antonopoulos, G. A. 2015. 'The only game in town?': football match-fixing in Greece. Trends in Organized Crime, 18, 196-211. 
Marty, D., Nicholson, P. \& Haas, U. 2015. Report to the President of the Union Cycliste Internationale. Lausanne: Cycling Indepent Reform Commission.

Mason, D. S., Thibault, L. \& Misener, L. 2006. An Agency Theory Perspective on Corruption in Sport: The Case of the International Olympic Committee. Journal of Sport Management, 20, 51.

Masters, A. 2015. Corruption in sport: From the playing field to the field of policy. Policy and Society, 34, 111-123.

McMasters, K. 2005. Nike and Popular Culture. In: BATCHELOR, B. (ed.) Basketball in America : from the playgrounds to Jordan's game and beyond. Binghamton, N.Y. : Haworth.

McNamee, M. J. 1998. Celebrating trust: virtues and rules in the ethical conduct of sports coaches. In: MCNAMEE, M. J. \& PARRY, S. J. (eds.) Ethics and sport. London : E \& FN Spon.

McNamee, M. J. \& Fleming, S. 2007. Ethics Audits and Corporate Governance: The Case of Public Sector Sports Organizations. Journal of Business Ethics, 425.

Menary, S. 2016. For the good of the game? Governance on the outskirts of international football. In: TRANSPARENCY INTERNATIONAL (ed.) Global Corruption Report: Sport. Abingdon, Oxon: Routledge.

Miari, R. C., de Mesquita, J. M. C. \& Pardini, D. J. 2015. Market Efficiency and Organizational Corruption: Study on the Impact on Shareholder Value. Brazilian Business Review (English Edition), 1-23.

Michie, J. \& Oughton, C. 2005. The Corporate Governance of Professional Football Clubs in England. Corporate Governance: An International Review, 13, 517-531.

Mitchell, K. 2016. Novak Djokovic tells of being offered $\$ 200,000$ to fix a match. The Guardian, Monday 18 January.

Mitchell, K. 2018. Tennis still defending its name despite integrity review warnings. The Guardian [Online]. Available: https://www.theguardian.com/sport/2018/apr/25/tennis-defendingintegrity-warnings-independent-review. 
Morgan, M. 2002. Optimizing the structure of elite competitions in professional sport - lessons from Rugby Union. Managing Leisure, 7, 41-60.

Nichols, P. M. 2012. The Psychic Costs of Violating Corruption Laws. Vanderbilt Journal of Transnational Law, 45, 145-210.

Nuwer, H. 1994. Sports Scandals, New York, Franlin Watts.

Omar Azfar, a., Young Lee, a. \& Anand Swamy, a. 2001. The Causes and Consequences of Corruption. The Annals of the American Academy of Political and Social Science, 42.

Paolo Mauro, a. 1995. Corruption and Growth. The Quarterly Journal of Economics, 681.

Pedersen, M. 2016. Examples of evolving good governance practices in sport. In: TRANSPARENCY INTERNATIONAL (ed.) Global Corruption Report: Sport. Abingdon, Oxon: Routledge.

Pielke, J. R. 2016. Obstacles to accountability in international sports governance. In: TRANSPARENCY INTERNATIONAL (ed.) Global Corruption Report: Sport. Abingdon, Oxon Routledge.

Pitt, L. F. \& Abratt, R. 1986. Corruption in Business -- Are Management Attitudes Right? Journal of Business Ethics, 5, 39-44.

Plachta, M. 2014. A. Council of Europe Adopts New Convention on the Manipulation of Sports Competitions. International Enforcement Law Reporter, 30, 408-411.

Pozsgai-Alvarez, J. 2018. The Quest for a Unified Theory of Coruption. Available: http://www.fcpablog.com/blog/2018/1/11/joseph-pozsgai-alvarez-the-quest-for-a-unifiedtheory-of-cor.html [Accessed 01/11/2018].

PWC 2011. Changing the game: Outlook for the global sports market to 2015.

PWC 2016. At the gate and beyond: Outlook for the sports market in North America through 2020. PWC Sports Outlook.

Quiñones, E. 2000. What is corruption? OECD Observer [Online]. [Accessed 23/11/2017].

Rader, B. G. 2008. Baseball : a history of America's game, Urbana, Ill., University of Illinois Press.

Ray, S. G. 2016. Fixed!: Cash and Corruption in Cricket, Harper Sport. 
Rayner, M. 2018. Rugby Union and professionalisation : elite player perspectives, London :

Routledge.

Reddiford, G. 1998. Cheating and self-deception in sport. In: MCNAMEE, M. J. \& PARRY, S. J. (eds.) Ethics and sport. London : E \& FN Spon.

Reid, J. 2014. Doped: The Real Life Story of the 1960s Racehorse Doping Gang, Newbury, Berkshire, Great Britain, Racing Post Books.

Roan, D. 2016. Doping: Russian athletes remain banned from competition including Olympics. $B B C$.

Rodenberg, R. M. \& Kaburakis, A. 2013. Legal and Corruption Issues in Sports Gambling. Journal of Legal Aspects of Sport, 23, 8-35.

Rodgers, W., Söderbom, A. \& Guiral, A. 2015. Corporate Social Responsibility Enhanced Control Systems Reducing the Likelihood of Fraud. Journal of Business Ethics, 131, 871-882.

Rose-Ackerman, S. 1978. Corruption : a study in political economy, New York : Academic Press. Rose-Ackerman, S. 1999. Corruption and government : causes, consequences, and reform, Cambridge : Cambridge Unversity Press.

Rose, J. 2017. The Meaning of Corruption: Testing the Coherence and Adequacy of Corruption Definitions. Public Integrity, 1-14.

Ryvkin, D., Serra, D. \& Tremewan, J. 2017. I paid a bribe: An experiment on information sharing and extortionary corruption. European Economic Review, 94, 1-22.

Sadoff, D. A. 2016. Senegal Unwilling to Extradite to France Former IAAF Official on Doping CoverUp-Related Charges. International Enforcement Law Reporter, 32, 45-47.

Sampford, C. J. G. 2006. Measuring corruption, Aldershot, Ashgate.

Schenk, S. 2016. What the anti-corruption movement can bring to sport: the experience of Transparency International Germany. In: TRANSPARENCY INTERNATIONAL (ed.) Global Corruption Report: Sport. Abingdon, Oxon: Routledge.

Schuchter, A. \& Levi, M. 2016. The fraud triangle revisited. Security Journal, 29, 107-121. 
Schwarz, E. C., Westerbeek, H., Liu, D., Emery, P. \& Turner, P. 2017. Managing sport facilities and major events, London : Routledge.

SIGA. 2017. Vision and Mission [Online]. Sport Integrity Global Alliance. Available: http://sigasport.net/vision-and-mission/ [Accessed 23/11/2017.

Sillaman, B. \& Bernardi, A. 11 January 2018 2018. Sillaman and Bernardi: Italy steps up whistleblowing regulation. The FCPA Blog [Online]. Available from: http://www.fcpablog.com/blog/2018/1/11/sillaman-and-bernardi-italy-steps-upwhistleblowing-regulati.html 2018].

Skillen, A. 1998. Sport is for losers. In: MCNAMEE, M. J. \& PARRY, S. J. (eds.) Ethics and sport. London : E \& FN Spon.

Smit, B. 2006. Pitch Invasion: Three Stripes, Two Brothers, One Feud: Adidas and the Making of Modern Sport, London, England, Allen Lane, Penguin Group.

Smith, A. C. T. \& Stewart, B. 2010. Review: The special features of sport: A critical revisit. Sport Management Review, 13, 1-13.

Smith, J. 2016. The Deal: Inside the World of a Super-Agent. Constable.

Spivey, N. 2012. The Ancient Olympics, Oxford, UK, Oxford University Press.

Sport England \& UK Sport 2016. A Code for Sports Governance. London.

Sport New Zealand 2009. Nine Steps to Effective Governance. 3rd ed.: Sport New Zealand.

Steenbergen, J. \& Tamboer, J. 1998. Ethics and the double character of sport: an attempt to systematize discussion of the ethics of sport. In: MCNAMEE, M. J. \& PARRY, S. J. (eds.) Ethics and sport. London : E \& FN Spon.

Steidlmeier, P. 1999. Gift Giving, Bribery and Corruption: Ethical Management of Business Relationships in China. Journal of Business Ethics, 121.

Stewart, B. \& Smith, A. 1999. The special features of sport. Annals of Leisure Research, 2, 87-99.

Szymanski, S. \& Kuypers, T. 2000. Winners and losers, London : Penguin. 
Taylor, C. 2018. Corruption and Anticorruption in Democratic Athens. In: KROEZE, R., VITORIA, A. \& GELTNER, G. (eds.) Anticorruption in History: From Antiquity to the Modern Era. Oxford: Oxford University Press.

The Secret Footballer 2013. Tales from the Secret Footballer, London, Guardian Books.

The Telegraph. 2010. F1 German Grand Prix: Ferrari 'cheats' Felipe Massa and Fernando Alonso fail media trial. The Telegraph, 26 July 2010.

Trace International Inc. 2018. Trace Bribery Risk Matrix [Online]. Available: https://www.traceinternational.org/trace-matrix [Accessed 19/06/2018.

Transparency International 2011. Bribe Payers Index 2011. Transparency International.

Transparency International 2016. Corruption Perceptions Index 2015. In: BEDDOW, R. (ed.). Transparency International.

Transparency International. 2017a. Anti-corruption Glossary [Online]. Available: https://www.transparency.org/glossary/term/bribery [Accessed 26.07.2017.

Transparency International. 2017b. What is Transparency? [Online]. Available: https://www.transparency.org/what-is-corruption\#what-is-transparency [Accessed 26.07.2017.

UCI 2017. 2016 Annual Report. Aigle, Switzerland: Union Cycliste Internationale.

UEFA. 2018. UEFA and the Council of Europe sign Memorandum of Understanding. Available: https://www.uefa.com/insideuefa/about-uefa/news/newsid=2561781.html [Accessed 04/06/2018].

UNODC. 2018. Corruption and sports [Online]. United Nations Office on Drugs and Crime. Available: http://www.unodc.org/unodc/en/corruption/sports.html [Accessed 04/06/2018.

US DOJ. 2017. High-Ranking Soccer Officials Convicted in Multi-Million Dollar Bribery Schemes. Available: https://www.justice.gov/usao-edny/pr/high-ranking-soccer-officials-convictedmulti-million-dollar-bribery-schemes [Accessed 07/06/2018]. 
US DOJ \& SEC 2012. A Resource Guide to the U.S. Foreign Corrupt Practices Act. In: JUSTICE, C. D. O. T. U. S. D. O. \& COMMISSION, E. D. O. T. U. S. S. A. E. (eds.). U.S. Department of Justice; U.S. Securities and Exchange Commission.

Walsh, A. \& Giulianotti, R. 2007. Ethics, money and sport : this sporting Mammon, London : Routledge.

Walsh, D. 2013. Seven Deadly Sins: My Pursuit of Lance Armstrong, London, Simon \& Schuster UK Ltd.

Weaver, P. 2010. Formula One, Integrity Nil: Ferrari and the worst brand of cheating. The Guardian, 27 July 2010.

Wolfe, D. T. \& Hermanson, D. R. 2004. The Fraud Diamond: Considering the Four Elements of Fraud. CPA Journal, 74, 38-42.

Wragge, A. \& Trusty, J. 2018. All About RICO. In: INC, T. I. (ed.) Bribe, Swindle or Steal.

Wu, A. 2018. Umpires allegedly involved in match fixing in UAE's unsanctioned Twenty20 league. Stuff [Online]. Available: https://www.stuff.co.nz/sport/cricket/101143849/umpiresallegedly-involved-in-match-fixing-in-uaes-unsanctioned-t20-league.

Xie, J. \& Yukio, F. 2013. A NEW FINDING FOR CORPORATE BOARD SIZE EFFECTS: EVIDENCE FROM JAPAN. Singapore Economic Review, 58, 1-12.

Yermack, D. 1996. Higher market valuation of companies with a small board of directors. Journal of Financial Economics, 40, 185-211.

Yost, M. 2010. Varsity Green: A behind the scenes look at culture and corruption in college athletics, Stanford, California, Stanford University Press.

Youd, K. 2014. Winter's Tale of Corruption: The 2022 FIFA World Cup in Qatar, the Impending Shift to Winter, and Potential Legal Actions against FIFA, The [comments].

Ziewacz, L. E. 2005. Dr. J, Bird, Magic, Jordan, and the Detroit Bad Boys: The NBA in the 1980s. In: BATCHELOR, B. (ed.) Basketball in America : from the playgrounds to Jordan's game and beyond. Binghamton, N.Y. : Haworth. 
